\title{
A THEORETICAL ANALYSIS OF SOCIAL ENTREPRENEURSHIP: THE CASE OF POLAND AND SOUTH AFRICA
}

\author{
Włodzimierz Sroka \\ WSB University, Poland and University of Johannesburg, South Africa \\ Natanya Meyer \\ University of Johannesburg, South Africa
}

\begin{abstract}
As global trends are moving more towards social inclusion and green entrepreneurship, many countries are changing or altering the way they want their firms to engage in business. This has sparked the interest in social entrepreneurship. Although a lot of research has been conducted on this issue, fewer country comparisons are available. Because country comparisons could lead to an improved understanding of the topic, the aim of this study is to provide a theoretical analysis on social entrepreneurship comparing Poland and South Africa, specifically focusing on the history, challenges, policy and government support initiatives, flagship programs and future trends in this field. The study follows a qualitative approach using document analysis by way of an intensive literature study. Findings based on the analysis indicate that social entrepreneurship is a global phenomenon and although it is of imperative importance as a means to improved social conditions, several barriers and challenges, which are noticeable in Poland and South Africa, are prevalent. As with traditional for-profit businesses, a main barrier for social enterprises is access to finance.
\end{abstract}

Keywords: social entrepreneurship; barriers; policy and government support; Poland; South Africa

DOI: http://dx.doi.org/10.15549/jeecar.v8i1.596

\section{INTRODUCTION}

Globally, the trend to engage on a more social level and give back to the community and protect the environment is picking up. This has led to the phenomenon of social entrepreneurship becoming more prominent (Teles \& Schachtebeck, 2019). Mair et al. (2006) mention that in the past two decades, social entrepreneurship has become more popular as it formally emerged as a new phenomenon by redefining the way people think and act to create social value. Although the formal notion of social entrepreneurship is rather new, the concept behind it is not new. Traditionally, social businesses were seen as non-profit relying on donations and other forms of funding (GIBS, 2018). However, this is fast changing, and businesses are using improved methods and business models to achieve and maintain 
financial sustainability (Ferencikova, 2018). The establishment of social enterprises can occur as a result of several factors which includes moral judgement, empathy, achievement and selfefficacy (Urban \& Teise, 2015). As social entrepreneurship focuses on solving and reducing social complications while achieving economic sustainability, it can be seen as a means to strengthen and improve social and economic conditions simultaneously in a country (Littlewood \& Holt, 2015).

Defining social entrepreneurship seems to be a challenge on its own as there is no consensus on how it should be defined (Choi \& Majumdar, 2014), and the phenomenon has been viewed from many perspectives (Martin \& Osberg, 2007). As mentioned, traditionally social enterprises were seen as non-profit driven, needing to raise funds from external sources to survive. Neck et al. (2009) refers to a processbased definition considering key terms such as creation of non-profits, new structures to solve social problems, innovative behavior for social objectives and social value creating activities. The notion of social entrepreneurship has been recognized as covering an extensive range of actions. Mair et al. 2006 mention that some of these actions include: entrepreneurial people enthusiastic to make a difference, businesses with a social purpose devoted to adding forprofit motivations to the non-profit sector, novel categories of philanthropists supporting venture capital-like 'investment' portfolios, and non-profit organizations that are reinventing the way they conduct business by focusing on lessons learned from the business world. Temple (2017) refers to social enterprises as businesses that are in existence purely to address and try to alleviate daily social challenges. They collect income from trading goods and services in the market, however profits are reinvested into the business and also into the community. Some of the major challenges being addressed by today's social entrepreneurs include: 1) the reduction of environmental impact; 2) creating work and new opportunities for people; 3 ) supporting the marginalized and vulnerable people in society; and 4) improving healthcare. Data reveal that social entrepreneurial start-ups are becoming more noticeable in communities and countries (Temple, 2017). In addition, social enterprises are becoming more financially diversified and moving away from traditional non-profit or donation-orientated models as they are building flexibility against a challenging and uncertain economic and political setting. Drayton (2011) refers to another aspect, collaborative entrepreneurship, a model in which everyone is seen as a 'change-maker'. He refers to this as the formation of 'change-maker' teams focusing on what is most needed in a community. These team players will contribute to changes as and when needed. Drayton (2011) further states that social entrepreneurs are essential team players in the 'change-maker' scenario and become role models inspiring others around them. Most important, social entrepreneurs are vital in this rapidly developing world where many systems fail its citizens.

For some, however, social entrepreneurship is viewed as just another type of entrepreneurship i.e., traditionally a for-profit model but solving social issues (Zahra et al., 2009). One thing that is clear is that social enterprises are multidisciplinary, and their size and aim can vary significantly. Although a formal, globally recognized definition must still be formulated, there could be consensus on the main dimensions that should be included in the overarching definition. These dimensions should include: 1 ) the explicit social mission of a social enterprise should be more important than profit: 2) they also provide a service to customers; 3 ) the proportion of traded revenue should distinguish them from not-for-profit organizations; 4) a proportion of profit/surplus should be reinvested; 5) they should be innovative; 6) they should provide an acceptable level of social impact; and 7) they should have a clear legal structure (Urban, 2008, Villeneuve-Smith \& Temple, 2015). Although these dimensions or guidelines seem rather straightforward, different economic and country environments may have an effect on the implementation thereof. In light of this, the aim of this study is to provide a theoretical analysis on social entrepreneurship comparing Poland and South Africa, specifically focusing on the history, challenges, policy and government support initiatives, flagship programs and future trends in this field. 


\section{METHODOLOGY}

A qualitative research approach was utilized for this study as it was deemed most APPROPRIATE considering it provides the chance to gain a deeper insight and understanding of the topic under discussion. Considering the nature of the research study, document analysis was used to gather information regarding the topic. This method permits a critical investigation of content collected from reliable and trustworthy sources. In this case, policy documents, newspapers, academic research papers and books formed the main sources of information. Using this approach allows for a systematic method reviewing and evaluating various documents in order to extract central themes or topics emanating from the research problem or question (Bowen, 2009). Additionally, Corbin and Strauss (2008) discuss that using this method can assist in the improvement and understanding of a topic. Document analysis is seen as a social research method and the justification for using it is the triangulation of information. It is unobtrusive in nature and therefore removes possible favoritism or bias from interactions with the study's sample population. Huysamen (1994), Babbie (2001) and Berryman (2019) all agree that it also encourages conceptual and contextual examination. Verifying findings and information from different trustworthy sources can create a confluence of information which could strengthen credibility (Bowen, 2009). Swart et al. (2014) state that results emanating from a document analysis permit verification with specific reference to the various documents. Advantages from using this methodology include: 1) saving cost and time when compared to other qualitative methods such as interviews or observation; 2 ) the ease of finding documents used in analysis; 3 ) limited to no human contact; and lastly, 4) documents are considered a reliable source which are freely accessible and non-reactive and thus can be viewed more than once (Bowen, 2009). Swart et al. (2014) further opine that results obtained from this form of analysis allow for verification specifically with reference to the various documents used. As suggested by Bowen (2009), the aforementioned documents (policy documents, newspapers, academic research papers and books) were selected as they contributed to the overall objective of the study. Furthermore, the documents could be considered credible, reliable, comprehensive and representative, as the source of all the documents used were known. The qualitative nature of the research findings focused on identifying themes that emerged from the research and conceptualizing it. These themes were identified as history, challenges, policy and government support initiatives, flagship programs and future trends in this field.

\section{Rationale for comparing Poland and South Africa}

Poland and South Africa were selected due to their similarity of past transitioning periods around the same time. Both these countries have only been considered democratic for between 25 to 30 years. South Africa started a true democracy in 1994 with the end of apartheid, and Poland was under communist rule up until 1990, both of which might have had some sort of an impact on the countries' entrepreneurial culture (Bobby-Evans, 2015; Nieuwenhuizen, 2016). Under communist rule, Poland experienced the majority of the industries belonging to the government and this severely impacted business development (Chakrabarty, 2014). Although Poland and South Africa share a similar political transition to some extent, the evolution of these two countries since democracy differs greatly. Table 1 summarizes some key aspects and differences between the selected countries. 
Table 1: Key aspects of Poland and South Africa

\begin{tabular}{|l|l|l|}
\hline & \multicolumn{1}{|c|}{ Poland } & \multicolumn{1}{|c|}{ South Africa } \\
\hline GDP per capita (2019) & $\$ 13811$ - high-income & $\begin{array}{l}\$ 6160 \text { - upper middle- } \\
\text { income }\end{array}$ \\
\hline $\begin{array}{l}\text { Unemployment rate }\left(2^{\text {nd }}\right. \\
\text { quarter of 2019) }\end{array}$ & $5.3 \%$ & $29 \%$ \\
\hline Economic growth & Positive high growth & $\begin{array}{l}\text { Stagnating moving } \\
\text { towards recession }\end{array}$ \\
\hline $\begin{array}{l}\text { Global standing and } \\
\text { competitiveness }\end{array}$ & Moving forward & Moved backwards \\
\hline $\begin{array}{l}\text { Governance } \\
\text { Infrastructure }\end{array}$ & $\begin{array}{l}\text { Stable policy, less } \\
\text { corruption }\end{array}$ & $\begin{array}{l}\text { Corruption, Policy } \\
\text { instability }\end{array}$ \\
\hline Skills level & Good and well-maintained & Poorly maintained \\
\hline
\end{tabular}

Sources: United Nation (2019); Trading Economics (2019); Prinsloo (2012); Rondinelli \& Shabbir (2003); Ahmed (2016); Jerzemowska et al. (2013)

As can be seen from Table 1, Poland seems more stable in various economic and political areas, and this also has an effect on entrepreneurial and social aspects. Analyzing these two countries regarding social entrepreneurial aspects may prove valuable, especially in the case of South Africa.

\section{Social entrepreneurship in South Africa History of social entrepreneurship in South Africa}

South Africa has a complex history, and with the introduction of a democracy in 1994, a lot of changes in the way business is seen and conducted were experienced (Bobby-Evans, 2015). This is the case for social entrepreneurship as well. Prior to 1994, many people were excluded from mainstream business activities, which as a result created many opportunities, especially in marginalized communities, for social entrepreneurs (Manyaka-Boshielo, 2017). This trend increased in the time after the end of apartheid, however, as the Government and many formal businesses were committed to improve the social, economic, and political injustice caused prior to
1994 (Littlewood \& Holt, 2018). The Global Entrepreneurship Monitor (GEM) reported on social entrepreneurial activity and found that early-stage social entrepreneurial activity was at a rate of 1.8 percent (Percentage of 18-64 population excluding individuals involved in any stage of entrepreneurial activity who are latent entrepreneurs and who intend to start a business within three years) which was similar to the global average rate (49 countries) (Herrington et al., 2010). As South Africa is one of the world's most unequal countries (2015 Gini coefficient of 63), many opportunities for social entrepreneurship exist (World Bank, 2020). Table 2 briefly lists some of the characteristics of social entrepreneurship preand post-1994.

Table 2 shows that a clear change in the trends regarding social entrepreneurship emerged after 1994 as a result of the start of the post-apartheid democratic era. Many of the existing social enterprises developed in an attempt to address issues caused by the pre1994 political system (Manyaka-Boshielo, 2017). 
Table 2: South Africa's social entrepreneurship trends over time - Basic characteristics and evolution

\begin{tabular}{|c|c|}
\hline Prior to 1994 & Post 1994 \\
\hline $\begin{array}{l}\text { Founding of the Pietermaritzburg Consumers Co- } \\
\text { Operative. }\end{array}$ & $\begin{array}{l}\text { Non-Profit Organizations Act (1997) repeals } \\
\text { restrictive Fundraising Act } 1978 .\end{array}$ \\
\hline $\begin{array}{l}\text { United Nations declares apartheid a crime } \\
\text { against humanity. }\end{array}$ & $\begin{array}{l}\text { End of transition to democracy, reduction in } \\
\text { international donor funding. }\end{array}$ \\
\hline Donors began funding local civil society. & $\begin{array}{l}\text { COFTA-World Fair } \text { Trade Organization } \\
\text { Africa; Amendments to Cooperative Act } \\
\text { (2005). }\end{array}$ \\
\hline $\begin{array}{l}\text { Growth of "civics" campaigning around local } \\
\text { material issues (e.g., better service delivery) and } \\
\text { wider political issues (overthrow of apartheid). }\end{array}$ & $\begin{array}{l}\text { Broad-Based Black Economic Empowerment } \\
\text { Act } 2004 \text { COFTA formed; Co-Operative } \\
\text { Development Policy for South Africa, 2004. }\end{array}$ \\
\hline $\begin{array}{l}\text { Agricultural co-operatives, trade union co- } \\
\text { operatives emerge. }\end{array}$ & Cooperatives Act (Act No. 14 of 2005). \\
\hline Ashoka Foundation opens offices in South Africa. & $\begin{array}{l}\text { SASIX launched } 2009 \text { ASEN and UnLtd South } \\
\text { Africa created. }\end{array}$ \\
\hline $\begin{array}{l}\text { Social entrepreneurship not so prevalent as a } \\
\text { main focus yet. }\end{array}$ & $\begin{array}{lrrr}\text { ILO social } & \text { enterprise } & \text { research } & \text { study } \\
\text { commences. } & & & \end{array}$ \\
\hline $\begin{array}{l}\text { Informal nature of social entrepreneurship taking } \\
\text { place in rural and marginalized areas. }\end{array}$ & $\begin{array}{l}\text { CSESE founded at the University of } \\
\text { Johannesburg; GIBS launches SECP; South } \\
\text { African Government New Growth Path } \\
\text { Framework. }\end{array}$ \\
\hline $\begin{array}{l}\text { Social and cultural role, especially in the rural } \\
\text { areas. }\end{array}$ & $\begin{array}{l}\text { Bertha Centre for Social Innovation and } \\
\text { Entrepreneurship launched University of } \\
\text { Cape Town; Social Enterprise World Forum, } \\
\text { Johannesburg. }\end{array}$ \\
\hline
\end{tabular}

Source: own elaboration based on: Manyaka-Boshielo, 2017; Bray, 2012; Littlewood and Holt, 2018; Urban, 2008, Littlewood and Holt, 2015.

Pre-1994, the concept of social entrepreneurship was not as well documented although it was in existence. In addition to the information listed in Table 2, several other initiatives were launched and implemented post-1994 which included, for example, PhytoTrade Africa, Social Enterprise Academy Africa and Impact Hub Johannesburg launches Social Impact Accelerator. Something that stood out post-1994 was the importance to right the wrongs from the past becoming more prominent; many private and public initiatives were formed, and social entrepreneurship started becoming a trend. Many hybrid models were developed, significant changes in the recognition of social enterprises were more prominent and it became trendy among the younger generation to engage in social enterprises. Social entrepreneurs were most likely to be educated up to the high school level or higher, males between 25 and 44 years old and urban-based.

\section{Policy of the South African Government and flagships programs}

As entrepreneurship has gained much attention in recent years within the political and economic sphere, policy development regarding it has also moved in a positive direction. Probably at the center of policy development in the South African context is the National Development Plan (NDP) compiled in 2011/12. 
The aim of the NDP is to address several challenges faced by South Africans, many of can be classified as social issues such as low quality of education, high unemployment, poor infrastructure, the spatial divide, an unstable economy, a deprived public health system, meagre quality of public services, corruption and racial issues (Alexander, 2017).

Among its various objectives, the NDP lists the creation of jobs and decrease of unemployment as its number one urgency in an attempt to increase economic growth, decrease poverty and ensure less inequality for South Africans. Emerging from this challenge, the NDP places importance on small business and entrepreneurship development (The Presidency, 2012). As in many other South African policies and initiatives flowing from the main vision of the NDP, entrepreneurship and small business development are mentioned numerous times. Many of the benefits and challenges linking to for-profit entrepreneurs also have relevance to social entrepreneurs, so these policies could to some extent also be relevant in the promotion and development of social entrepreneurship. The NDP focusses on the following areas with regard to entrepreneurship development (The Presidency, 2012):

- Ensure that entrepreneurship training among the youth cohort is improved in order to identify opportunities;

- Ensure that South Africans form a unity to enhance fertile conditions for entrepreneurship;

- Transform ownership to include previously disadvantaged groups by creating an enabling environment for Black owned small businesses;

- Promote entrepreneurship in schools;

- Promote skills development within new and underutilized sectors of the economy;

- Ensure that Education and Training (FET) colleges identify scarce skills and introduce entrepreneurship training programs;

- Improve and promote entrepreneurial skills development in sectors such as agriculture and tourism;

- Provide financial support;
- Ensure better coordination of government agencies.

Many other policies surrounding entrepreneurship also exist, emanating from the Department of Trade and Industry, the Department of Economic Development and the Department of Small Business Development, for example (Meyer, 2018). Although many of these policies and initiatives are aimed at traditional entrepreneurial development, many have the aim to resolve a social issue and the basic principles of these policies also align with social entrepreneurial activities. South Africa has several purely social entrepreneurship initiatives and international support organizations of which some of these include: SAB Foundation Social Innovation Awards (an annual competition acknowledging innovative and impactful social entrepreneurs); US Ashoka Foundation; Schwab Foundation; Aspen Network of Development Entrepreneurs (ANDE); Lifeco UnLtd South Africa; Skoll Foundation (which provides established social enterprises with funding to scale their venture and increase reach); African Diaspora Network (which provides a knowledge-sharing platform for investors; Social Enterprise Academy Africa (which provides learning and development for social entrepreneurs); The South African Social Investment Exchange (SASIX) (South Africa's first online social investment stock exchange that connects social enterprises with interested investors) (British Council, 2016).

\section{Key challenges and barriers of growth}

According to Bosma et al. (2015), social entrepreneurs are inclined to be rather optimistic in their future growth ambitions. Being optimistic about future growth is important as this could have a very positive effect on intention to grow and future investment possibilities (Meyer, 2019). However, as with traditional for-profit entrepreneurs, social entrepreneurs also face a myriad of challenges. Of these challenges, probably the most mentioned one, or the highest reason for failure, is chronic financial constraints (Martin \& Osberg, 2007). Traditionally, social entrepreneurs have been reliant on self-funding, donations, and similar types of funding as they followed a purely non- 
profit business model. Recent trends have seen refined business models incorporating a more hybrid approach, however (Moss et al., 2008). On a global scale, and specifically in developing countries with enormous social needs such as South Africa, social enterprises should be thriving and not just surviving (Fin24, 2018). Littlewood and Holt (2015) opine that there is a multitude of environmental issues causing challenges for social entrepreneurs. These include living conditions, barriers to entry, availability of venture capital and bargaining power of buyers and suppliers. Furthermore, infrastructure in rural communities, where many of these businesses have their primary place of business, is in poor condition, creating increased pressure concerning accessibility. Another challenge is government policy and legislation. Many social businesses struggle to access enterprise development funds due to the nature of their business models and institutional imperfections (Roth \& Kostova, 2003). Temple (2017) lists the five main challenges faced by social entrepreneurs: procurement of grant funding, cash flow, limited demand and unfavorable economic environment, access to debt equity finance and public sector procurement policies. As social enterprises differ so much in their offerings and blended-value agendas, it can make the formulation of metrics and standardization a challenging aspect (Smith et al., 2013). In addition, calculating performance or impact to society is also not easy and this has a direct effect on securing finance (Nicolls, 2010). While many of the challenges social entrepreneurs face is globally recognizable, countries such as South Africa has some unique challenges. For example, as many social enterprises are formed by previously marginalized community members in their own communities, basic business tools such as business cards or having a proper cost structure is lacking (Webmaster, 2011).

\section{Future trends}

It is clear that social entrepreneurship has a very distinct place in society and that more of these ventures will emerge and also unfortunately fail in the future. Some social entrepreneurs are becoming more innovative in their business models, and this might be a possible solution to more sustainable income. Specifically, in developing countries such as South Africa, the role that social entrepreneurs play in development is crucial (Littlewood \& Holt, 2015). Unfortunately, very few (less than $2 \%$ of the population between 18 and 64 years) are involved in this activity (Bosma et al., 2015). Future trends involve building more sustainable business models that have commercial relevance with social impact and tailoring products or services that provides offerings in different ways to different markets i.e. commercial and social simultaneously.

\section{Social entrepreneurship in Poland}

\section{History of social entrepreneurship in Poland}

Poland has a long tradition regarding the growth and development of social entrepreneurship. The first examples of cooperatives and non-profit organizations appeared in Poland at the beginning of the 19th century (at that moment the country was occupied by the German, Russian and AustriaHungarian empires). In general, three main historical periods of their development can be distinguished (Table 3 ).

The information presented in Table 3 shows both similarities and differences in particular periods. But one issue seems obvious: the real re-interest in the concept of social entrepreneurship increased radically in the third period, due mostly to the accession into the European Union (EU). For example, the European Commission, under projects such as the Social Business Initiative (SBI), EU Program for Employment and Social Innovation (EaSI), European fund for Strategic Investment (EFSI) among others have made investment of up to EUR 500000 available for social entrepreneurs (European Commission, 2017). 
Table 3: Poland's social entrepreneurship trends over time - Basic characteristics and evolution

\begin{tabular}{|c|c|c|}
\hline Prior to Second World War & $\begin{array}{c}1945-1989 \text { (during } \\
\text { communism) }\end{array}$ & Post 1990 \\
\hline $\begin{array}{l}\text { Existence of two basic types of } \\
\text { social enterprises: associations, } \\
\text { foundations and other voluntary } \\
\text { organizations, as well as co- } \\
\text { operatives. }\end{array}$ & $\begin{array}{l}\text { Associations, foundations, and } \\
\text { co-operatives not permitted to } \\
\text { choose their governing } \\
\text { officials, nor set their goals, } \\
\text { nor undertake activities } \\
\text { without the permission of the } \\
\text { authorities. }\end{array}$ & $\begin{array}{l}\text { Necessity to re-build the } \\
\text { potential of the social } \\
\text { enterprises. }\end{array}$ \\
\hline $\begin{array}{l}\text { A significant economic potential } \\
\text { of the co-operative movement - } \\
\text { around } 20 \% \text { of adult Poles } \\
\text { belonged to a co-operative. }\end{array}$ & $\begin{array}{l}\text { In the late } 1940 \text { s and early } \\
\text { 1950s, all foundations, and the } \\
\text { majority of associations, were } \\
\text { dissolved by the communist } \\
\text { authorities, while their assets } \\
\text { and properties were taken } \\
\text { over by the state (without any } \\
\text { compensation). }\end{array}$ & $\begin{array}{l}\text { Three phases in the } \\
\text { institutionalization of social } \\
\text { enterprises: 1) the } \\
\text { renaissance of social } \\
\text { enterprises (1989-1995), 2) } \\
\text { stabilization of social } \\
\text { enterprises in terms of } \\
\text { numbers and their } \\
\text { enhancement in terms of } \\
\text { quality (1996-2002), and 3) } \\
\text { institutionalization of social } \\
\text { enterprises under the impact } \\
\text { of the European Union (EU) } \\
\text { (since } 2003 \text { until now). }\end{array}$ \\
\hline $\begin{array}{l}\text { Social economy in Poland } \\
\text { regarded as the important } \\
\text { segment of the national } \\
\text { economy (over } 20 \text { thousand co- } \\
\text { operatives, a strong position of } \\
\text { mutual in the insurance market, } \\
\text { annual co-operative share in the } \\
\text { overall retail turnover at a level } \\
\text { of } 4-5 \% \text {, however in the case of } \\
\text { provision of agricultural } \\
\text { products, it was much higher } \\
\text { and amounted to } 12 \% \text { ). }\end{array}$ & $\begin{array}{l}\text { Legacy of the communist } \\
\text { regime strongly influenced } \\
\text { Polish social enterprises in the } \\
\text { third period and most of social } \\
\text { enterprises had to build their } \\
\text { economic potential from } \\
\text { scratch. }\end{array}$ & $\begin{array}{l}\text { Support by public (from the } \\
\text { state and EU) and private } \\
\text { funds. }\end{array}$ \\
\hline $\begin{array}{l}\text { Social and cultural role, } \\
\text { especially in the rural areas. }\end{array}$ & & $\begin{array}{l}\text { Significant change in the } \\
\text { recognition of social } \\
\text { enterprises. }\end{array}$ \\
\hline
\end{tabular}

Source: own elaboration based on: Herbst, 2008, p. 125; Ciepielewska-Kowalik 2013; Greblikaite et al., 2015.

There are many other such initiatives that were implemented post-1990. Furthermore, as the importance of entrepreneurship and, specifically, social entrepreneurship is still growing, associations such as the Organization for Economic Co-operation (OECD), EU,
European Commission, to name but a few, have various projects and programs assisting the growth and development of social entrepreneurship in Europe and many other countries (OECD, 2016). A project mapping the number of social enterprises in the EU was also 
initiated in an attempt to more accurately measure the impact of social entrepreneurship. This in future will add more empirical data to the actual number, size, legal form and type of business activity which will be valuable in measuring the impact of social entrepreneurship.

\section{Policy of the Polish Government and flagships programs}

Research and analytical studies carried out in Poland show an increase in interest and recognition for social entrepreneurship among representatives of various fields of science economics, management, law, as well as sociology, philosophy and psychology, with the vast majority of studies being theoretical (Pacut, 2018). Also, Poland, as a country, promotes the growth and development of social enterprises. A special program, the so-called National Program for Social Economy Development, was launched by the Polish Government in 2014. It is worth mentioning that it has the status of an official governmental document. One should add that it was the first comprehensive legal act that fully recognized social economy in Poland, and, first of all, it determined the key directions of public support for the social economy and social entrepreneurship. In other words, the position of the social economy has been given a new, and at the same time very high, status and thus chances of development.

This program clearly defines the entities that can be regarded as the social enterprise: 1) social enterprises, as they constitute the most, being the core of the social economy (e.g. cooperatives); 2) public benefit entities conducting economic activity (nongovernmental organizations); 3) reintegration entities (e.g. occupational activity firms, social integration centers; their aim is socio-economic integration of people threatened by the social exclusion); and 4) informal initiatives (e.g. cooperatives, student cooperatives) (Ciepielewska-Kowalik, 2015).

In addition, the said program also states that social economy organizations have several major goals, such as to integrate the socially excluded (or threatened by social exclusion), to create workplaces, to provide welfare services, and to support local development. They should also contribute significantly to employment growth, social coherence, and development of social capital (Greblikaite et al., 2015).

Despite these programs, further growth of social enterprises in Poland requires constant support. There are several forms of support for social enterprises, the most important of which are direct subsidies, as well as preferential loans and credits, access to free information and advice services, as well as - and use of guarantee funds and credit guarantees. There is also a worldwide known program by the international association, one of the goals of which is to identify, select and empower social entrepreneurs. Those social entrepreneurs usually initiate, through a bottom-up approach, a chain of autocatalytic systemic changes initiatives, making the process endogenous and empowering people, groups, communities, and societies (Praszkier \& Nowak, 2012).

Another example of the initiative which promote social enterprises is NESsT and JPMorgan Chase Foundation, which have announced the first awards for the best social enterprise business plan in 2014. Generally, it is necessary to state that unless, these initiatives and programs are varied in their scope and aims, they contribute to the promotion of social enterprise and social entrepreneurship development in Poland (Greblikaite et al., 2015).

\section{Key challenges and barriers of growth}

Poland has experienced dynamic growth and development of its social enterprise sector, however it faces a number of barriers. Typical obstacles that social entrepreneurs encounter include financial problems, lack of knowledge and qualifications and processes enabling the construction and maintenance of a high-quality product or service. There are, however, some other obstacles resulting from their social nature, which include, for example, lack of trust in the initiatives undertaken by social enterprises, low level of activity of local communities, lack of social trust for partnership building skills and collaborating to achieve common objectives and lack of cooperation between social enterprises. No wonder, then, that some representatives of social enterprises claim it is easier to find an employee or 
customer by hiding the social nature of the business.

Given these facts, some basic challenges for social enterprises in Poland can be presented. First, it seems that a key role should be played by self-governance and local leadership. In other words, social entrepreneurship should be based on self-governance (e.g., local leader, mayor, etc.). This requires joint preparation programs and action plans (Praszkier et al., 2014). Second, a mental change is equally important. Years of communism have brought very negative consequences (e.g., apathy, lack of belief in one's own strengths), which even now still are not easy to overcome (although in Poland in general a strong sense of community is being observed). Third, a modification of the education system that is better adjusted to the real needs, with more focus on practice rather than theory, is necessary. This relates to all levels of education but especially tertiary education (Greblikaite et al., 2016). One also cannot forget about Social Integration Centers that focus on reintegration of foreigners, immigrants, and addicted people. This factor plays a huge role nowadays, as the country attracts millions of emigrants, including some from 'culturally far regions', from different countries. For sure, this aspect is expected to have more and more importance.

\section{Future trends}

As Lin (2019, p.1) stated, "today, social enterprises contribute to all facets of society, offering supportive and life-changing facilities, engaging a massive number of individuals and generating millions of dollars". In other words, social entrepreneurship is becoming more like mainstream entrepreneurship. Social entrepreneurs will need to innovate by creating solutions to create value for society. They will have to offer superior, innovative or betterquality solutions for the issues they identify in their societies and globally. Nowadays, the emphasis on social components in the general mainstream of innovation activity is one of the strongest grounds for the successful functioning and development of enterprises (Shpak et al., 2017; Khan et al., 2021). At the same time, one should remember that the operations of social enterprises are aimed at both making profit and addressing social and (or) environmental issues (Urmanaviciene \& Cizikiene, 2017). Consumers also are increasingly paying more attention to the importance of ethical and environmentally friendly aspects, as illustrated by the fair-trade and "buy-social" phenomenon, which advocates the human being's centrality in economic undertakings (OECD/European Union, 2017; Pakurár et al., 2020).

Poland is becoming similar to developed countries and even now, in some aspects (e.g. functioning of the Warsaw Stock Exchange), is regarded as the first developed country coming from the former Soviet Union block. Being similar to a developed country refers to a variety of aspects related to the functioning of the economy and society, including social entrepreneurship, and it means then that these trends will be applied to Poland.

Historical data from Poland and practices from other countries indicate the involvement of social enterprises in the development of the tourism industry. The inclusion of social enterprises in economic activity in the field of tourism is a chance to recreate the patterns of management in this field that match the expectations of modern and postmodern tourists (Waligóra, 2018).

\section{DISCUSSION}

The analysis that has been conducted shows that there are both similarities and significant differences between the two countries. The latter is nothing special, given that even between culturally and geographically close countries there are substantial differences, as was confirmed by Kliestikova and Janoskova (2017), who analyzed the profiles of consumers in different countries. They revealed, inter alia, that despite the fact that Slovak Republic and Czech Republic have common socio-cultural past due to existence of the former Czechoslovakia, they were grouped into the different clusters.

The factor which can certainly be considered as a common feature of both countries is the similar period of the existence of a democracy (30 and 26 years for Poland and South Africa respectively) in which a number of events promoting and stimulating social 
entrepreneurship were launched. It is worth adding that in the beginning of the 1990s both countries, in addition to having similar populations (37.56 million for South Africa and 38.04 million for Poland), also shared an autocratic political history (apartheid for South Africa and communism for Poland). There were also significant differences, however. South Africa, even though it is one of the most developed countries in Africa, had a much higher level of poverty was much higher in South Africa than Poland (which, even so, is among the poorest countries in Europe). Addressing poverty, no doubt created a huge impetus for social entrepreneurship activity in both countries, however the last years show that South African and Poland have followed different development paths (see Table 1).

Another similarity is the approach each country has taken with respect to the development of social entrepreneurship. In the case of South Africa, it was the National Development Plan launched in 2011/12 which aim to address several challenges faced by South Africans, especially poverty reduction and addressing the very high unemployment level, one of the most prominent problems of the country. Indeed, these two issues created a very prominent platform for social entrepreneurship. In contrast, the Polish government implemented the National Program for Social Economy Development in 2014, which was the official governmental document fully recognizing the social economy in the country and determining the key directions of its development and public support. Though both documents were official, they were different concerning their main aspects. In South Africa, encouraging social entrepreneurship mostly relates to the 'fight' against poverty and high unemployment, whereas in Poland support for social entrepreneurship not only was to help alleviate poverty but also help with the development of the economy in general. In Poland's case, both problems were solved: the social program initiated by the Government after 2015 caused poverty levels to diminish significantly (it is similar to the average in EU), and in turn unemployment levels in Poland are one of the lowest in Europe. To provide some context, though, to the differences between the countries in terms of the different results from social entrepreneurship, in the last 30 years South Africa's population has grown by 20 million (to 58 million), while Poland's has stayed rather constant. As a result, the scale of the poverty and unemployment problems in the two countries are not comparable.

It is also worth adding that in South Africa there were more initiatives stimulating the growth of social entrepreneurship, which can be seen by comparing the data presented in Tables 2 and 3. Despite this fact, the real effects of the social entrepreneurship to, for example, lower unemployment levels, are higher in Poland. A partial explanation of this can be that Poland has been a member of the EU, which makes it possible for Polish companies, even social ones, to attract support from EU funds, regardless of their form. In addition, Polish social entrepreneurs may use the benefits of other funds, such as the Visegrad Fund or Norway Funds. The Visegrad Fund is an international donor organization established in 2000 by the governments of the Visegrad Group countriesCzechia, Hungary, Poland and Slovakia - to promote regional cooperation in the Visegrad region (V4) as well as between the V4 region and other countries, especially in the Western Balkans and Eastern Partnership regions. South African social enterprises do not have such support.

Our analysis also showed that social entrepreneurs in Poland and South Africa face very similar problems in day-to-day operations. These include financial problems (banks are rather unwilling to offer credit and loans to social businesses) and a lack of skilled and qualified employees. But based on the observations of other countries (including developed ones), one may state that it is a common problem of all social enterprises regardless of the location.

\section{CONCLUSION AND RECOMMENDATIONS}

Social entrepreneurship is a specific type of business that, like traditional companies, accomplishes economic goals, but places more emphasis on the achievement of social goals. Given this fact, many countries stimulate and promote the growth of social enterprises, treating them as useful instruments for economic development. 
This study has analyzed the existence and functioning of social entrepreneurship in South Africa and Poland, two culturally and geographically different countries. Though having similar starting points, both countries followed different development paths that had an impact on the growth of the social entrepreneurship.

Our study contributes to theory in several aspects. First, it analyzes the functioning of social entrepreneurship in two countries that, on one hand are similar to some extent (e.g. historical circumstances and period of democratic governments) but have substantial differences (e.g. current macro-economic indicators). To the best of our knowledge, it is the first study of its type in comparing Poland and South Africa on a social entrepreneurial level. Second, it represents an international approach which is much more interesting than a single country analysis only, which we believe adds value to the study of social entrepreneurship. Third, the results of our study may be useful for the formulation of the research hypotheses in further surveys.

Based on our research, we present the following recommendations to improve the situation that social entrepreneurs face now:

- Focus more on impact and long-term sustainability. This can be done by ensuring that projects are screened before they commence and that a proper status quo analysis (if possible) is done in an attempt to measure the impact;

- Focusing on the development of clear action plans. Plan the business or intervention beforehand. In many cases, due to the passion and enthusiasm of social entrepreneurs to make a difference, important steps in the planning phase are left out;

- Social businesses must be seen as a business. Social entrepreneurs should remember that social enterprises should also be financially viable in order to survive and should therefore opt for some sort of a hybrid for-profit model; and

- Involve local communities on all levels: As far as possible, social entrepreneurs should try to involve the community, education institutions, local businesses and government in an attempt to develop cooperative networks.

The current study is theoretical and conceptual, and this may be deemed as a restraint. Although this study provided information on the importance of social entrepreneurship and the differences and similarities between Poland and South Africa, it is not without limitations. First, the exploratory and qualitative nature of the study could be seen as one dimensional, future studies of an empirical nature could provide more robustness to the topic. Future studies building on this study will include empirical findings from social businesses in the two sample countries to determine their challenges and barriers. In addition, including more countries to the analysis may prove to be of value as this may assist in identifying best practices and possible solutions to the challenges and barriers faced by social entrepreneurs. In addition, some kind of longitudinal study (e.g. conducted every 5-10 years) could provide valuable information on the direction in which the situation regarding social entrepreneurship will evolve. Despite this fact, we strongly believe that this study presents the real situation with regard to social entrepreneurship in both countries.

\section{ACKNOWLEDGEMENTS}

The research was funded within the auspices of the program of the Polish Ministry of Science and Higher Education entitled 'Regional Initiative of Excellence' in 2019-2022, project number $018 /$ RID/2018/19, the amount of funding was PLN 10,788,423.16.

\section{REFERENCES}

Ahmed, M. A. 2016. Corporate Governance in the South African Development Community. LLM- University of the Western Cape.

Alexander, M. 2017. The National Development Plan: A vision for 2030. https://www.brandsouthafrica.com/governa nce/ndp/the-national-development-plan-avision-for-2030. Last Accessed: 6 March 2017. 
Babbie, E. 2001. “The Practice of Social Research". (9th Ed.). Belmont, CA, Wadsworth Thomson Learning.

Berryman, D. R. 2019. “Ontology, Epistemology, Methodology, and Methods: Information for Librarian Researchers". Medical reference services quarterly, 38(3): 271-279.

Bobby-Evans, A. 2015. Apartheid legislation in South Africa.

http://africanhistory.about.com/library/bl/bl salaws.htm. Last accessed: 3 September 2015.

Bosma, N., T. Schott, S. Terjesen, and P. Kew. 2015. "Special Topic Report: Social Entrepreneurship, Global Entrepreneurship Monitor". Babson College. https://www.gemconsortium.org/file/open? fileId=49542. Last Accessed: 28 September 282017.

Bowen, G. A. 2009. "Document analysis as a qualitative research method". Qualitative Research Journal, 9(2): 27-40.

Bray, R. 2012. Roddy Bray's Story-Letters from Southern Africa. http://www.capetown.at/letters/soc_entrep. htm. Last Accessed: 7 March 2020.

British Council. 2016. "Social enterprise in a global context: The role of Higher Education Institutions. Country Brief: South Africa". Plymouth University.

Chakrabarty, B. 2014. "Communism in India: Events, Processes and Ideologies", New Delhi: Oxford University Press. doi:10.1093/acprof:oso/9780199974894.00 1.0001

Choi, N., and S. Majumdar. 2014. "Social entrepreneurship as an essentially contested concept: Opening a new avenue for systematic future research". Journal of Business Venturing, 29(3): 363-376.

Ciepielewska-Kowalik A., Pieliński, B., Starnawska, M. and Szymańska, A. (2015) Social enterprise in Poland: institutional and historical context, ICSEM Working Papers, No. 11, Liege: The International Comparative Social Enterprise Models (ICSEM) Project, pp. 1-32. https://www.iapsocent.be/sites/default/files/Poland\%20\%20Ciepielewska-Kowalik\%20et\%20al.pdf. Last accessed: 10 April 2020.
Ciepielewska-Kowalik, A. 2013. "Trends and challenges for social enterprises in Poland. A new model of social investments and social cohesion. Paper presented at $4^{\text {th }}$ EMES International Research Conference on Social Enterprise "If Not For Profit, For What? And How?”, July 1-4, 2013, University of Liege, Liege.

Ciepielewska-Kowalik, A. 2015. "Socioeconomic, political and historical context of the emergence of the Social Economy in childcare in Poland (1989-2014). Looking for social inclusion and cohesion enhancement" http://www.ciriec2015.com/resources/files/ CIRIEC2015_0259_paper.pdf. Last accessed: 20 November 2019.

Corbin, J. A. and A. Strauss. 2008. Basics of Qualitative Research(3rd ed.). Thousand Oaks, CA: Sage.

Drayton, B. 2011. Collaborative Entrepreneurship How Social Entrepreneurs Have Learned to Tip the World by Working in Global Teams. MIT Press with Harvard University and George Mason University.

European Commission. 2017. Supporting entrepreneurs and the self-employed Social entrepreneurs.

https://ec.europa.eu/social/main.jsp?catId=9 52\&intPageId=2914\&langId=en\#: :text=Acc ess\%20to\%20finance\&text=helps\%20social\%2 0enterprises\%20access\%20investments,and\% 20Social\%20Innovation\%20(EaSI).\&text=The \%20grant\%20serves\%20as\%20an,EUR\%20500 \%2C000\%20in\%20social\%20enterprises. Last Accessed: 12 January 2021.

Ferencikova, S. 2018. Internationalization of small and medium-sized enterprises from central and eastern Europe: A theoretical framework. Journal of Eastern European and Central Asian Research, 5(2):1-9.

Fin24. 2018. SA's social entrepreneurs - going from surviving to thriving https://www.fin24.com/Opinion/sas-socialentrepreneurs-going-from-surviving-tothriving-20180615. Last Accessed: 10 February 2020.

GIBS. 2018. Social enterprises in South Africa discovering a vibrant sector. Gordon Institute of Business, University of Pretoria. 
Greblikaite, J., W. Sroka, and N. Gerulaitiene. 2016. "Involving young people in Polish and Lithuanian social enterprises by fostering entrepreneurial skills and abilities as entrepreneurial opportunity at university". Entrepreneurial Business and Economics Review, 4(3): 131-152. https://doi.org/10.15678/EBER.2016.040310.

Greblikaite, J., W. Sroka, and J. Grants. 2015. "Development of Social Entrepreneurship in European Union: Policy and Situation of Lithuania and Poland". Transformations in Business \& Economics, 14(2B(35B): 376-396.

Herbst, J. 2008. Polski trzeci sektor w świetle teorii przedsiębiorstwa społecznego, in: J.Dąbrowska (Ed.), Od trzeciego sektora do przedsiębiorczości społecznej - wyniki badań ekonomii społecznej w Polsce, Warszawa: Stowarzyszenie Klon/Jawor

Herrington, M., J. Kew, and P. Kew. 2010. "Tracking entrepreneurship in South Africa a GEM Perspective". Global Entrepreneurship Monitor (Vol. 1). Cape Town: Graduate School of Business, University of Cape Town. http://doi.org/10.1017/ СBO9781107415324.004

Huysamen, G. K. 1994. "Methodology for the social and behavioural sciences". Southern Book Publishers.

Jerzemowska, M., A. Golec, B. Gabriel, O. Martyniuk, and E. Sokołowska. 2013. Corporate governance in Poland: strengths, weaknesses and challenges. (In 5th International Conference" Economic challenges in enlarged Europe"). Tallinn University of Technology.

Khan, M. A., Máté, D., Abdulahi, E. M., Sadaf, R., Khan, A., M. M., Popp, J., Oláh, J. 2021. “Do institutional quality, innovation and ICT technologies promote financial market development?" European Journal of International Management, 14(2), DOI: 10.1504/EJIM.2020.10025994

Kliestikova, J., Janoskova, K. 2017. "Branding with understanding: How national profile of consumer influences brand value perception". Marketing and Management of Innovations, 3, 149-157. DOI: 10.21272/mmi.2017.3-14.
Lin, S. 2019. "These social entrepreneurship trends will hit all the emotions in 2020." https://gritdaily.com/socialentrepreneurship-trends-2020/. Last accessed: 5 January 2020.

Littlewood, D. and D. Holt, 2018. “Social entrepreneurship in South Africa: Exploring the influence of environment". Business \& Society, 57(3): 525-561.

Littlewood, D., and D. Holt. 2015. "Social entrepreneurship in South Africa: Exploring the influence of environment". Business \& Society, 0007650315613293.

Mair, J., J. Robinson, and K. Hockerts. 2006. Social Entrepreneurship. New York: Palgrave Macmillan.

Manyaka-Boshielo, S. J. 2017. "Social entrepreneurship as a way of developing sustainable township economies". HTS Theological Studies, 73(4): 1-10.

Martin, R. L., and S. Osberg. 2007. "Social entrepreneurship: The case for definition." Stanford Social Innovation Review, 5(2): 2839.

Meyer, N. 2018. South African female entrepreneurs' intention to remain in business. Vanderbijlpark: North-West University (Doctoral thesis).

Meyer, N. 2019. "South African female entrepreneurs' business styles and its influence on various entrepreneurial factors". Forum Scientiae Oeconomia, 7(2): 25-35.

Moss, T. W., G. T. Lumpkin, and J. Short. 2008. The dependent variables of social entrepreneurship research. Frontiers of Entrepreneurship Research: 28(21): Article 3.

Neck, H., C. Brush, and E. Allen. 2009. "The landscape of social entrepreneurship". Business Horizons, 52(1): 13-19.

Nieuwenhuizen, C. 2016. "Entrepreneurial intentions amongst Master of Business students in efficiency-driven economies: South Africa and Poland". Southern African Business Review, 20(1): 313-335.

OECD (Organisation for Economic Co-operation and Development). 2016. Social Entrepreneurship in Europe- An OECD- 
European Commission Project. https://www.oecd.org/cfe/leed/socialentrepreneurship-oecd-ec.htm. Last Accessed: 12 January 2021.

OECD/European Union. 2017. "Main trends in social enterprise development" in: Boosting Social Enterprise Development: Good Practice Compendium, OECD Publishing, Paris. DOI: 10.1787/9789264268500-4-en

Pacut, A. 2018. Rozwój przedsiębiorczości społecznej w Polsce -trajektoria zmian i rola otoczenia instytucjonalnego, $\mathrm{PhD}$ thesis, Uniwersytet Ekonomiczny w Krakowie Wydział Gospodarki i Administracji Publicznej.

Pakurár, M., Khan, M. A., Benedek, A., Oláh, J. 2020. "The impact of green practices, cooperation and innovation on the performance of supply chains using statistical method of meta-analysis". Journal of International Studies, 13(3): 111-128. DOI: 10.14254/2071-8330.2020/13-3/8.

Praszkier, R., A. Zabłocka-Bursa, and E. Jozwik. 2014. "Social Enterprise, Social Innovation and Social Entrepreneurship in Poland: A National Report", November 2014. University of Warsaw. Retrieved from: http://ashoka-cee.org/poland/wpcontent/uploads/sites/4/2017/03/EFESEIISNational-Report-Poland.pdf. Last accessed: 10 January 2020.

Praszkier, R., and A. Nowak. 2012. Social Entrepreneurship: Theory and Practice. New York: Cambridge University Press.

Prinsloo, F. C. 2012. Good Governance in South Africa: A Critical Analysis. Public Development Management: University of Stellenbosch.

Rondinelli, D. A. and G. S. Cheema. 2003. Reinventing government for the twentyfirst century: An introduction. Reinventing government for the twenty-first century: state capacity in a globalizing society. Bloomfield: Kumarian Press, pp1-13.

Roth, K. and T. Kostova. 2003. Organizational coping with institutional upheaval in transition economies. Journal of World Business, 38: 314-330.

Shpak N., L. Satalkina, W. Sroka, and S. Hittmar. 2017. "The social direction of enterprises' innovation activity". Polish Journal of Management Studies, 16(1): 187-201.

Smith, W. K., M. Gonin, and M. L. Besharov. 2013. "Managing social-business tensions: A review and research agenda for social enterprise". Business Ethics Quarterly, 23(3): 407-442.

Swart, J. J., M. J. Swanepoel, and J. Surujlal. 2014. A critical analysis of government spending on sport. African Journal for Physical, Health Education, Recreation and Dance, October 2014 (Supplement 2.2): 251-265.

Teles, D. and C. Schachtebeck. 2019. "Entrepreneurial Orientation in South African Social Enterprises'. Entrepreneurial Business and Economics Review, 73): 8297. DOI 10.15678/EBER.2019.070305.

Temple, N. 2017. The Future of Business: State of Social Enterprise Survey 2017, Social Enterprise UK. https://sewfonline.com/wpcontent/uploads/2017/09/2017-State-ofSocial-Enterprise.pdf. Last Accessed: 8 April 2017.

The Presidency. 2012. National Development Plan 2030: Our future-make it work. Pretoria: Government Printer.

Trading Economics. 2019. Unemployment rate. https://tradingeconomics.com/southafrica/unemployment-rate. Last accessed: 8 August 2019.

United Nations. 2019. Country Classifications. https://www.un.org/development/ desa/dpad/tag/ country-classifications/. Last accessed: 11 August 2019.

Urban, B. 2008. "Social entrepreneurship in South Africa: Delineating the construct with associated skills". International Journal of Entrepreneurial Behavior \& Research, 14(5): 346-364.

Urban, B. and H. Teise. 2015. "Antecedents to social entrepreneurship intentions: An empirical study in South Africa". Management Dynamics: Journal of the Southern African Institute for Management Scientists, 24(2): 36-52.

Urmanaviciene A., and J. Cizikiene. 2017. "The challenges of managing of voluntary work in social enterprises". Forum Scientiae 
Oeconomia, 5(3): 89-100. DOI: 10.23762/FSO_VOL5NO3_17_.

Villeneuve-Smith, F., and N. Temple. 2015. "Leading the World in Social Enterprise", Social Enterprise: UK.

Waligóra, A. 2018. "Potencjał przedsiębiorczości społecznej w turystyce". Studia Oeconomica Posnaniensia, 6(10): 111-120. DOI: 10.18559/SOEP.2018.10.7

Webmaster. 2011. Students explore social entrepreneurship in post-apartheid South Africa. https://www.northeastern.edu/sei/2011/09/ students-explore-social-entrepreneurshipin-post-apartheid-south-africa/. Last Accessed: 12 February 2020.

World Bank. 2020. The World Bank in South Africa: Overview. https://www.worldbank.org/en/country/sou thafrica/overview. Last Accessed: 7 March 2020.

Zahra, S. A., E. Gedajlovic, D. O. Neubaum, and J. M. Shulman. 2009. "A typology of social entrepreneurs: Motives, search processes and ethical challenges". Journal of Business Venturing, 24(5): 519-532.

\section{ABOUT THE AUTHORS}

Natanya Meyer, email: natanyam@uj.ac.za

Dr. Włodzimierz Sroka is an associate professor at the Management Department of WSB University, Dąbrowa Górnicza (Poland) as well as visiting professor at the University of Johannesburg (South Africa). His research interests include strategic management, with particular emphasis on interorganisational cooperation, marketing, CSR and business ethics, entrepreneurship, and social entrepreneurship as well as innovations. He is the editor, co-editor, associate editor and editorial board member as well as reviewer for a number of national and international journals.

Dr. Natanya Meyer is an associate professor in the College of Business and Economics, University of Johannesburg. She is part of the DHET-NRF SARChI Entrepreneurship Education Chair. Her research focuses on entrepreneurial and economic related topics. She is a co-editor, editorial board and scientific committee member as well as reviewer for several national and international journals. 